Scientific journal

PHYSICAL AND MATHEMATICAL EDUCATION

Has been issued since 2013.

Науковий журнал

ФІЗИКО-МАТЕМАТИЧНА ОСВІТА

Видається з 2013.
ISSN 2413-158X (online)

ISSN 2413-1571 (print)

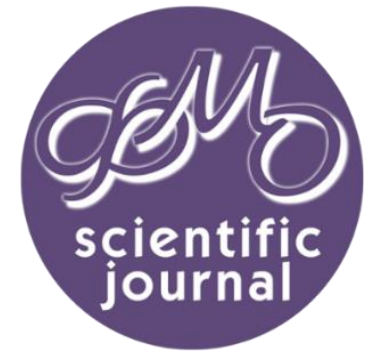

http://fmo-journal.fizmatsspu.sumy.ua/

Воскоглоу М. Представлення моделі "5 E" за допомогою ланцюга Маркова. Фізико-математична освіта. 2019. Випуск 3(21). С. 7-11.

Voskoglou Michael Gr. A Markov chain representation of the "5 E's" instructional treatment. Physical and Mathematical Education. 2019. Issue 3(21). P. 7-11.

DOI 10.31110/2413-1571-2019-021-3-001

Michael Gr. Voskoglou

Graduate Technological Educational Institute of Western Greece, Greece voskoglou@teipat.gr; mvoskoglou@gmail.com

\title{
A MARKOV CHAIN REPRESENTATION OF THE “5 E's” INSTRUCTIONAL TREATMENT
}

ABSTRACT

Formulation of the problem. The socio-constructive theories of learning have become very popular during the last decades for teaching mathematics. The " $5 E^{\prime} s$ " is an instructional model based on the principles of social constructivism that has recently become very popular, especially in school education, for teaching mathematics. Each of the 5 E's describes a phase of learning which begins with the letter "E" - Engage, Explore, Explain, Elaborate, Evaluate. Depending on the student reactions, there are forward or backward transitions between the three middle phases (explore, explain, elaborate) of the $5 E^{\prime}$ 's model during the teaching process. The " $5 E^{\prime} s^{\prime}$ " model allows students and teachers to experience common activities, to use and build on prior knowledge and experience and to assess their understanding of a concept continually.

Materials and methods. Probabilistic methods of analysis are used.

Results. The mathematical representation of the " 5 E's" model is attempted by applying an absorbing Markov chain on its phases. A Markov Chain (MC) is a stochastic process that moves in a sequence of steps (phases) through a set of states and has a one-step memory. A finite $M C$ having as states Si the corresponding phases $E i, i=1,2, \ldots, 5$, of the " $5 E^{\prime} \mathrm{s}^{\prime}$ instructional model is introduced. A classroom application is also presented illustrating the usefulness of this representation in practice. The following application took place recently at the Graduate Technological Educational Institute of Western Greece for teaching the concept of the derivative to a group of fresher students of engineering.

Conclusions. The Markov chain representation of the " $5 \mathrm{E}^{\prime} \mathrm{s}$ " model provides a useful tool for evaluating the student difficulties during the teaching process. This is very useful for reorganizing the instructor's plans for teaching the same subject in future.

KEY WORDS: constructivism, socio-cultural theories for learning, "5 E's" instructional model, absorbing Markov chains.

\section{INTRODUCTION}

The "5 E's" instructional treatment. Mathematics teaching is intended to promote the learning of mathematics. However, while theory provides us with lenses for analyzing learning, the position of mathematics teaching remains theoretically anomalous and underdeveloped. We might see one of the problems to lie in the relationships between learning, teaching and the practice of teaching. Theories help us to analyze, or explain, but they do not provide recipes for action; rarely do they provide direct guidance for practice. The application of the socio-constructive theories for learning to teaching mathematics has started during the 1980's, when the failure of the introduction of the "new mathematics" to the school curricula had already become more than evident to everybody.

The idea that knowledge is a human construction supported by the experience, first stated by Vico in the $18^{\text {th }}$ century and further extended by Kant, affected greatly the epistemology of Piaget, who is considered to be the forerunner of the theory of constructivism for the process of learning. This theory appeared formally by von Clasersfeld who developed his ideas in the Piaget foundation of USA in 1975 (Glasersfeld, 1987). The constructivist approach is based on the following two principles:

- Knowledge is not passively received from the environment, but it is actively constructed by synthesizing past knowledge and experience with the new information.

- The "coming to know" is a process of adaptation based on and constantly modified by the individual's experience of the world.

On the other hand, the socio-cultural theories for learning are based on the Vygotsky's ideas claiming that knowledge is a product of culture and social interaction. Learning takes place when the individuals engage socially to talk and act about shared problems or interests (Elbers, 2003; Jaworski, 2006; Wenger, 1998). The Communities of Practice are groups of people (experts or practitioners in a particular field) who share a concern for something they do and learn how to do it better as they interact regularly, having therefore the opportunity to develop themselves personally and professionally (Goos, 2014; 
Voskoglou, 2019; Wenger, 1998). The combination of the constructivism with the socio-cultural ideas is known as social constructivism (Driver et al., 1994; Jaworski, 2006).

The " $5 \mathrm{E}^{\prime} \mathrm{s}$ " is an instructional model based on the principles of social constructivism that has become recently very popular, especially in school education, for teaching mathematics (Enhancing Education, 2019). Each of the 5 E's describes a phase of learning which begins with the letter "E". Those phases are the following:

- Engage $\left(E_{1}\right)$ : this is the starting phase, which connects the past with the present learning experiences and focuses student thinking on the learning outcomes of the current activities.

- Explore $\left(E_{2}\right)$ : during this, phase students explore their environment to create a common base of experiences by identifying and developing concepts, processes and skills.

- Explain $\left(E_{3}\right)$ : in this, phase students explain and verbalize the concepts that they have been explored and they develop new skills. The teacher has the opportunity to introduce formal terms, definitions and explanations for the new concepts and processes and to demonstrate new skills or behaviours.

- Elaborate $\left(E_{4}\right)$ : In this, phase students develop a deeper and broader conceptual understanding and obtain more information about areas of interest by practicing on their new skills and behaviours.

- Evaluate $\left(E_{5}\right)$ : this is the final step of the " $5 E^{\prime} s^{\prime}$ " instructional model, where learners are encouraged to assess their understanding and abilities and teachers evaluate student skills on the new knowledge.

Depending on the student reactions, there are forward or backward transitions between the three middle phases (explore, explain, elaborate) of the $5 \mathrm{E}$ 's model during the teaching process. The " $5 \mathrm{E}$ 's" model allows students and teachers to experience common activities, to use and build on prior knowledge and experience and to continually assess their understanding of a concept. Although it has been mainly applied in school education (Keeley, 2017) the 5 E's can be used with students of all ages, including adults (Hee et al., 2013). In this article, we shall obtain a mathematical representation of the " 5 E's" model with the help of the theory of finite absorbing Markov Chains.

Finite absorbing Markov Chains. A Markov Chain (MC) is a stochastic process that moves in a sequence of steps (phases) through a set of states and has a one-step memory. That means that the probability of entering a certain state in a certain step depends on the state occupied in the previous step and not in earlier steps. This is known as the Markov property. However, for being able to model as many real life situations as possible by using MCs, one could accept in practice that the probability of entering a certain state in a certain step, although it may not be completely independent of previous steps, it mainly depends on the state occupied in the previous step (Kemeny \& Snell, 1963). When the set of states of a MC is a finite set, then we speak about a finite MC. For general facts on finite MCs we refer to the book (Kemeny \& Snell, 1976).

A. Markov introduced the basic concepts of MCs in 1907 on coding literal texts. A number of leading mathematicians, such as A. Kolmogorov, W. Feller, etc, developed the MC theory. However, only from the 1960 's the importance of this theory to the natural, social and most of the applied sciences has been recognized (Bartholomew, 1973; Kemeny \& Snell, 1963; Suppes \& Atkinson, 1960).

Let us consider a finite $M C$ with $n$ states, say $S_{1}, S_{2}, \ldots, S_{n}$, where $n$ is a non-negative integer, $\mathrm{n} \geq 2$. Denote by $p_{i j}$ the transition probability from state $S_{i}$ to state $S_{j}, i, j=1,2, \ldots, n$; then the matrix $A=\left[p_{i j}\right]$ is called the transition matrix of the MC. Since the transition from a state to some other state (including itself) is the certain event, we have that

$$
p_{i 1}+p_{i 2}+\ldots+p_{i n}=1 \text {, for } \mathrm{i}=1,2, \ldots, \mathrm{n} \text {. }
$$

A state of a MC is called absorbing if, once entered, it cannot be left. Further a $M C$ is said to be an absorbing MC (AMC), if it has at least one absorbing state and if from every state it is possible to reach an absorbing state, not necessarily in onestep. Working with an AMC with $\mathrm{k}$ absorbing states, $1 \leq \mathrm{k}<\mathrm{n}$, one brings its transition matrix $A$ to its canonical form $A^{*}$ by listing the absorbing states first and then makes a partition of $A^{*}$ as follows

$$
A^{*}=\left[\begin{array}{c|c}
I_{k} & O \\
- & - \\
R & Q
\end{array}\right] .
$$

In the above partition of $A^{*}, I_{k}$ denotes the unitary $\mathrm{kX} \mathrm{k}$ matrix, $O$ is a zero matrix, $R$ is the $(\mathrm{n}-\mathrm{k}) \mathrm{Xk}$ transition matrix from the non-absorbing to the absorbing states and $Q$ is the $(n-k) X(n-k)$ transition matrix between the non-absorbing states.

It can be shown ((Voskoglou \& Perdikaris, 1991), Section 2) that the square matrix $I_{n-k}-Q$, where $I_{n-k}$ denotes the unitary $(n-k) x(n-k)$ matrix, is always an invertible matrix. Then, the fundamental matrix $N$ of the AMC is defined to be the inverse matrix of $I_{n-k}-Q$. Therefore ((Morris, 1978), Section 2.4)

$$
N=\left[n_{i j}\right]=\left(I_{n-k}-Q\right)^{-1}=\frac{1}{D\left(I_{n-k}-Q\right)} \operatorname{adj}\left(I_{n-k}-Q\right) .
$$

In equation (3) $D\left(I_{n-k}-Q\right)$ and $\operatorname{adj}\left(I_{n-k}-Q\right)$ denote the determinant and the adjoin of the matrix $I_{n-k}-Q$ respectively. It is recalled that the adjoin of a matrix $M$ is the matrix of the algebraic complements of the transpose matrix $M^{t}$ of $M$, which is obtained by turning the rows of $M$ to columns and vice versa. It is also recalled that the algebraic complement $m_{i j}$ 'of an element $m_{i j}$ of $M$ is calculated by the formula

$$
m_{i j}{ }^{\prime}=(-1)^{i+j} D_{i j}
$$

where $D_{i j}$ is the determinant of the matrix obtained by deleting the $i$-th row and the $j$-th column of M. 
It is well known ((Kemeny, \& Snell, 1976), Chapter 3) that the element $n_{i j}$ of the fundamental matrix $N$ gives the mean number of times in state $s_{i}$ before the absorption, when the starting state of the AMC is $s_{j}$, where $s_{i}$ and $s_{j}$ are non-absorbing states.

\section{RESULTS AND DISCUSSION}

The AMC model. We introduce a finite MC having as states $S_{i}$ the corresponding phases $E_{i}, i=1,2, \ldots, 5$, of the " $5 E^{\prime} s^{\prime}$ " instructional model. According to the description of the " $5 \mathrm{E}^{\prime} \mathrm{s}$ " model, performed in our Introduction, the flow diagram of this chain is that shown in Figure 1

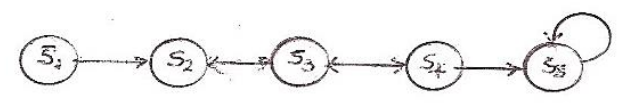

Figure 1. The flow-diagram of the MC

From the flow-diagram of Figure 1 it becomes evident that the above chain is an AMC with $S_{1}$ being its starting state and $S_{5}$ being its unique absorbing state. The minimum number of steps before the absorption is 4 and this happens when we have no backward transitions between the three middle states $S_{2}, S_{3}$ and $S_{4}$ of the chain.

The transition matrix of the chain is the matrix

$$
\begin{aligned}
& \begin{array}{lllll}
\mathrm{S}_{1} & \mathrm{~S}_{2} & \mathrm{~S}_{3} & \mathrm{~S}_{4} & \mathrm{~S}_{5}
\end{array}
\end{aligned}
$$

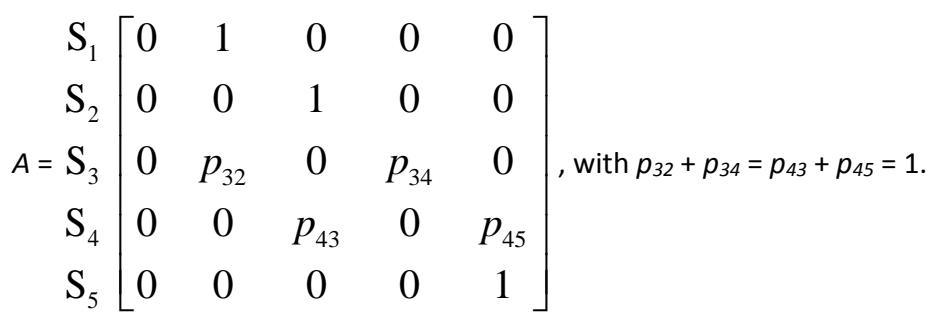

The canonical form of $A$ is the matrix

$$
\begin{aligned}
& \begin{array}{l|llll}
\mathrm{S}_{5} & \mathrm{~S}_{1} & \mathrm{~S}_{2} & \mathrm{~S}_{3} & \mathrm{~S}_{4}
\end{array} \\
& A^{*}=\begin{array}{c}
\mathrm{S}_{5} \\
- \\
\mathrm{S}_{1} \\
\mathrm{~S}_{2} \\
\mathrm{~S}_{3} \\
\mathrm{~S}_{4}
\end{array}\left[\begin{array}{ccccccc}
1 & \mid & 0 & 0 & 0 & 0 \\
- & - & - & - & - & - \\
0 & \mid & 0 & 1 & 0 & 0 \\
0 & \mid & 0 & 0 & 1 & 0 \\
p_{45} & \mid & 0 & p_{32} & 0 & p_{34} \\
R & 0 & p_{43} & 0
\end{array}\right]=\left[\begin{array}{c:c}
I_{1} & O \\
- & - \\
R &
\end{array}\right] . \\
& \text { Then } \left.I_{4}-Q=\left[\begin{array}{cccc}
1 & -1 & 0 & 0 \\
0 & 1 & -1 & 0 \\
0 & -p_{32} & 1 & -p_{34} \\
0 & 0 & -p_{43} & 1
\end{array}\right] \text { and } D\left(I_{4}-Q\right)=\mid \begin{array}{ccc}
1 & -1 & 0 \\
-p_{32} & 1 & -p_{34} \\
0 & -p_{43} & 1
\end{array}\right]=1-p_{34} p_{43}-p_{32} \text {. }
\end{aligned}
$$

Further, by equation (4), the algebraic complement of the element $m_{11}=1$ of the transpose matrix

$$
\left(I_{4}-Q\right)^{t}=\left[\begin{array}{cccc}
1 & 0 & 0 & 0 \\
-1 & 1 & -p_{32} & 0 \\
0 & -1 & 1 & -p_{43} \\
0 & 0 & -p_{34} & 1
\end{array}\right] \text { is equal to }\left|\begin{array}{ccc}
1 & -p_{32} & 0 \\
-1 & 1 & -p_{43} \\
0 & -p_{34} & 1
\end{array}\right|=1-p_{43} p_{34}-p_{32} .
$$

In the same way we calculate the algebraic complements of all the other elements of $\left(I_{4}-Q\right)^{t}$ and replacing their values and the value of $D\left(I_{4}-Q\right)$ to equation (3) we find that 


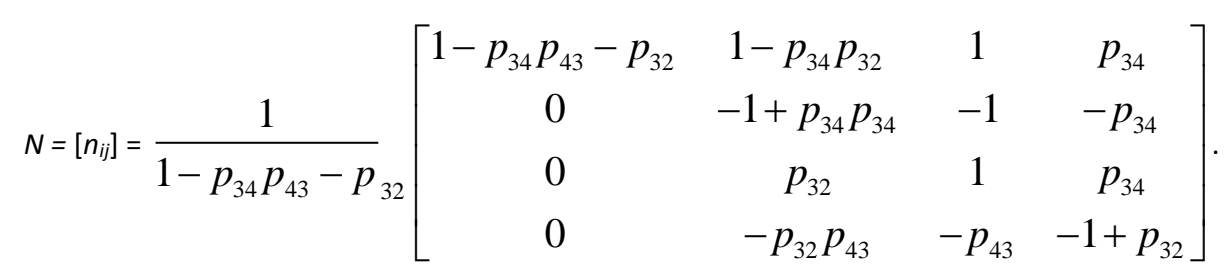

Since $S_{1}$ is the starting state of the above $A M C$, it becomes evident that the mean number of steps before the absorption is given by the sum

$$
T=n_{11}+n_{12}+n_{13}+n_{14}=\frac{3-2 p_{43} p_{34}-p_{32}+p_{34}}{1-p_{34} p_{43}-p_{32}}
$$

It is also clear that the bigger is $\mathrm{T}$, the more are the student difficulties during the teaching process with the " $5 \mathrm{E}^{\prime} \mathrm{s}$ " instructional treatment. Another factor of the student difficulties is the total time spent for the completion of the teaching process. However, the time is usually fixed in a formal teaching procedure in the classroom, which means that in this case $\mathrm{T}$ is the unique measure of the student difficulties.

A classroom application. The following application took place recently at the Graduate Technological Educational Institute of Western Greece for teaching the concept of the derivative to a group of fresher students of engineering. The instructor used the " $5 \mathrm{E}$ 's" instructional treatment as follows:

Engage: The student attention was turned to the fact that the definition of the tangent of a circle as a straight line having a unique common point with its circumference does not hold for other curves (e.g. for the parabola). Therefore, there is a need to search for a definition of the tangent covering all cases and in particular of the tangent at a point of the graph of a given function.

1. Explore: The discussion in the class leads to the conclusion that the tangent at a point $A$ of the graph of a given function $y=f(x)$ can be considered as the limit position of the secant line of the graph through the points $A(a, f(a))$ and $B(b, f(b))$, when the point $B$ is moving approaching to A either from the left, or from the right (see (Voskoglou, 2017b), Figure 1). However, the slope of the secant line $\mathrm{AB}$ is equal to $\frac{f(b)-f(a)}{b-a}$, therefore the slope of the tangent of the graph at $\mathrm{A}$ is equal to the limit of the above ratio when $b$ tends to $a$.

Explain: Based on what it has been discussed at the phase of exploration, the instructor presents the formal definition of the derivative number $f^{\prime}(a)$ at a point $\mathrm{A}(a, f(a))$ of a given function $y=f(x)$ as the limit (if there exists) of $\frac{f(b)-f(a)}{b-a}$ when $a \rightarrow b$, and of the tangent of the graph of $y=f(x)$ at A as the straight line through A with slope $f^{\prime}(a)$. Some examples follow of calculating the derivative at a given point of a function and the tangent of its graph at this point. Then the definition of the derivative function $y^{\prime}=f^{\prime}(x)$ of the function $y=f(x)$ is given and suitable examples are presented to show that its domain is a subset of the domain of $y=f(x)$.

Elaborate: Here the fact that the derivative $y^{\prime}=f^{\prime}(x)$ expresses the rate of change of the function $y=f(x)$ with respect to $x$ is emphasized and its physical meaning is also presented connected to the speed and the acceleration at a moment of time of a moving object under the action of a steady force. The fundamental properties of the derivatives follow (sum, product, composite function, etc.) as well as a list of formulas calculating the derivatives of the basic functions and applications of them.

Evaluate: At the end of the teaching process, a number of exercises and problems analogous to those solved in the classroom was given to students on the purpose of checking at home their understanding of the subject. A week later, a written test was performed in the classroom enabling the instructor to assess the student progress.

Another important thing remaining for the instructor was to evaluate the student difficulties during the teaching process, which could help him in reorganizing properly his plans for teaching the same subject in future. This was succeeded with the help of the above developed MC representation of the " 5 E's" model in the following simple way.

The instructor noticed that the student reactions during the teaching process led to 2 transitions of the discussion from state $S_{3}$ (explain) back to state $S_{2}$ (explore). Therefore, since from state $S_{2}$ the chain moves always to $S_{3}$ (Figure 1), we had 3 in total transitions from $S_{2}$ to $S_{3}$. The instructor also noticed 3 transitions from $S_{4}$ (elaborate) back to $S_{3}$. Therefore, since from state $S_{3}$ the chain moves always to state $S_{4}$ (Figure 1), we had 4 in total transitions from $S_{3}$ to $S_{4}$. In other words, we had $3+3=6$ in total "arrivals" to $S_{3}, 2$ "departures" from $S_{3}$ to $S_{2}$ and 4 "departures" from $S_{3}$ to $S_{4}$. Therefore $p_{32}=\frac{2}{6}$ and $p_{34}=\frac{4}{6}$. In the same way one finds that $p_{43}=\frac{3}{4}$ and $p_{45}=\frac{1}{4}$. Replacing the above values of the transition probabilities to equation (5) one finds that the mean number $\mathrm{T}$ of steps before the absorption of the $\mathrm{MC}$ is equal to 14 . Consequently, since the minimum number of steps before the absorption is 4 , the students faced significant difficulties during the teaching process. This means that the instructor should find ways to improve his teaching procedure for the same subject in future.

\section{CONCLUSION}

The theory of MCs, being a smart combination of Linear Algebra and Probability, offers ideal conditions for the study and mathematical modelling of a certain kind of situations depending on random variables. In the paper at hands a mathematical representation of the " $5 \mathrm{E}^{\prime} \mathrm{s}$ " teaching model was developed with the help of the theory of AMCs enabling the instructor to evaluate the student difficulties during the teaching process. This is very useful for reorganizing his (her) plans for 
teaching the same subject in future. An application of this representation was also presented to teaching the concept of the derivative to engineering students. Although the development of the AMC model was proved to be quite laborious requiring the calculation of 17 in total determinants of third order (the determinant of the matrix $I_{4}-Q$ and the algebraic complements of its transpose matrix), its final application is very simple. The only thing needed for this purpose is the calculation by the instructor of the transitions of the $A M C$ from $S_{3}$ back to $S_{2}$ and from $S_{4}$ back to $S_{3}$. Several other applications of MCs to education have been attempted by the present author in earlier works (e.g. see Chapters 2 and 3 of the book (Voskoglou, 2017a) and it is hoped that this research could be continued in future.

\title{
References
}

1. Bartholomew, D.J. (1973). Stochastic Models for Social Processes. London: J. Wiley and Sons.

2. Driver, R., Asoko, H., Leach, J.; Mortimer, E. \& Scott, P. (1994). Constructing Scientific Knowledge in the Classroom, Educational Researcher, 23(7), 5-12.

3. Elbers, E. (2003). Learning and teaching mathematics in a community of inquiry, Educational Studies in Mathematics, 54, 77-99.

4. Enhancing Education. (2019). The 5 E's. Retrieved from: http://enhancinged.wgbh.org/research/eeeee.html.

5. Ernest, P. (1998). Social Constructivism as a Philosophy of Mathematics, Albany, New York, State University of New York Press.

6. Goos, M. (2014). Communities of practice in mathematics teacher education, in S. Lerman (Ed.), Encyclopedia of Mathematics Education, Dordrecht, Netherlands: Springer, 82-84.

7. Hee, J.W., Lee, E.J., Park, H.J., Chang, A.K. \& Kim, M.J. (2013). Use of the $5 E$ learning cycle model combined with problembased learning for fundamentals of a nursing course, Journal of Nursing Education, 52 (12), 681-689.

8. Jaworski, B. (2006). Theory and practice in mathematics teaching development: Critical inquiry as a mode of learning in teaching, Journal of Mathematics Teacher Education, 9, 187-211.

9. Keeley, P. (2017). Embedding Formative Assessment into the 5 E Instructional Model, Science and Children, 55 (4), 28-31.

10. Kemeny, J. G. \& Snell, J. L. (1963). Mathematical Models in the Social Sciences, New York: Ginn and Company.

11. Kemeny, J. G. \& Snell J. L. (1976). Finite Markov Chains, New York: Springer - Verlag.

12. Morris, A. O. (1978). An Introduction to Linear Algebra, Berkshire, England: Van Nostrand Beinhold Company Ltd.

13. Suppes, P. \& Atkinson, R.S. (1960). Markov Learning Models for Multiperson Interactions, Stanford, California: Stanford University Press.

14. Glasersfeld, E. (1987). Learning as a Constructive Activity. In C. Janvier (Ed), Problems of representation in the teaching and learning of mathematics, Lawrence Erlbaum, Hillsdale, N. J., USA, 3-17.

15. Voskoglou, M. Gr. \& Perdikaris, S. C. (1991). A Markov chain model in problem-solving, International Journal of Mathematical Education in Science and. Technology, 22, 909-914.

16. Voskoglou, M. Gr. (2017a). Finite Markov Chain and Fuzzy Logic Assessment Models: Emerging Research and Opportunities. Columbia, SC, USA: Createspace.com-Amazon.

17. Voskoglou, M. Gr. (2017b). A Note on the Graphical Representation of the Derivatives, Scientific Journal of Physical and Mathematical Education, 2(12), 9-16.

18. Voskoglou, M.Gr. (2019). Communities of Practice for Teaching and Learning Mathematics, American Journal of Educational Research, 7(6), 186-191.

19. Wenger, E. (1998). Communities of Practice: Learning, Meaning, and Identity, Cambridge: Cambridge University Press, UK.

\section{ПРЕДСТАВЛЕННЯ МОДЕЛІ "5 Е" ЗА ДОПОМОГОЮ ЛАНЦЮГА МАРКОВА} Майкл Воскоглоу

Анотація.

\author{
Вищий технологічний освітній інститут Західної Греції, Школа технологічних застосувань, Греція
}

Постановка проблеми. Соціально-конструктивні теорії навчання стали дуже популярними у викладання математики протягом останніх десятиліть. "5 E" - че навчальна модель, заснована на принципах сочіального конструктивізму, що останнім часом стала дуже популярною при викладання математики, особливо в шкільній освіті. Кожен із "5 Е" описує окремий етап навчання, який починається з літери "Е" - Займайтесь, Досліджуйте, Пояснюйте, Розробляйте, Оцінюйте. Залежно від реакцій учнів, існують переходи вперед або назад між трьома середніми фазами (Досліджуйте, Пояснюйте, Розробляйте) моделі "5 E" під час навчального процесу. Модель “5 Е” дозволяє учням та викладачам здійснювати спільну діяльність, використовувати, будувати на основі попередніх знань та досвіду нові знання, постійно оцінювати своє розуміння концепції.

Матеріали і методи. Використовуються ймовірнісні методи аналізу.

Результати. Для математичного зображення моделі "5 Е" намагаємося застосувати поглинаючий ланцюг Маркова на його фазах. Ланцюг Маркова - це стохастичний процес, який рухається послідовно кроками (фазами) через набір станів і має одно

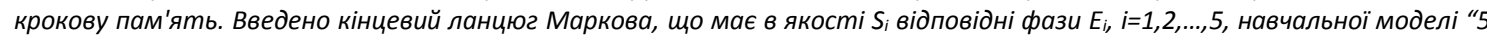
E". Також в статmі представлено застосування моделі "5 E" до роботи в аудиторії з класом, що ілюструє корисність чієї моделі на практиці. Апробація такого застосування відбулося нещодавно в Вищому технологічному навчальному інституті Західної Греції для вивчення поняття похідної у групи студентів, майбутніх інженерів, на перших курсах.

Висновки. Представлення моделі "5Е" за допомогою ланцюга Маркова є корисним інструментом для оцінювання труднощів студентів під час навчального процесу. Застосування ланцюга Маркова є корисним $і$ з позиції реорганізації планів викладача щодо викладання того ж предмета в майбутньому.

Ключові слова: конструктивізм, сочіокультурні теорії навчання, навчальна модель "5 Е", ланчюг Маркова. 